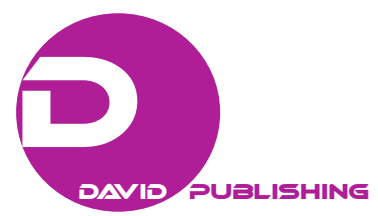

\title{
Cartography of the Higher Education and Research System in France: Strategy, Programming, Evaluation, and Operational Units*
}

\author{
Alves Baptista, Tatiane \\ Rio de Janeiro State University (UERJ), Rio de Janeiro, Brazil
}

\begin{abstract}
This article addresses the set of changes that have occurred in French higher education (HE) and research system, aiming at a general characterization of its current configuration. For that, it describes the main processes of the system reconfiguration based on the analysis of the current legislation, identifying significant changes concerning the strategic dimension, programming, financing, operationalization, and evaluation. Thus, it focuses on three systematically articulated spheres. In order to understand the reasons behind such changes, this article recovers the global context of adjustments in the so-called "neoliberal wave”-specifically the New Public Management (NPM), so as to place such evidence on the new cartographic framework of HE in France, concluding that the ongoing transformations are part of a global trend in the sector, involving economic elements, the issue of the public financing model, the management of human resources in a logic of competition, and the sophistication of the control mechanisms of the academic work. On the other hand, there are also changes towards the resignification of universities' role as protagonists in the production of innovative and socio-economic solutions. Both trends weigh heavily on one of the most important pillars of higher education and research (HER) institutions, namely the issue of autonomy.
\end{abstract}

Keywords: higher education and research, university, management and governance, autonomy

\section{Introduction}

In a global context, the areas of research, development, and innovation have gained significant importance for the countries' political, economic, and strategic plan. Throughout the 1990's to the 2000's, a significant global wave raised the issue of innovation, consequently stimulating new productions and processes to ensure the competitiveness and sustainability among the countries.

This lever has generated a significant reordering of the legal framework that involves the countries' research system. Notably, with more visibility and impact since the turn of the 21st century, the European

\footnotetext{
*Acknowledgement: Work under the supervision of C. Paradeise. She is a sociologist who studied at the Institut d'Études Politiques in Paris, at EHESS and at the University of Michigan in Ann Arbor. She took her Ph.D.s (thèse de 3ème cycle and Thèse d'état) in Paris-Sorbonne. She taught at several universities and held many positions of responsibility in French institutions, such as the CNRS Humanities and Social Sciences department (SHS) from 1990 to 1994 and Ecole Normale Supérieure de Cachan. Emeritus Professor of Sociology at the Paris Est-Marne-la-Vallée University, she participated in the creation of the Institut Francilien Recherche, Innovation, and Société (IFRIS), based in Paris, where she is a honorary president.

Alves Baptista, Tatiane, Ph.D., associate professor, researcher at Rio de Janeiro State University (UERJ), Latin American Faculty of Social Sciences-FLACSO and the LaboratoireInterdisciplinaire Sciences, Innovations, Société-LISIS/France.
} 
community, at a strategic level, has produced an intense reordering process that led to the creation of new structures, new financing mechanisms, and new processes of evaluation of its higher education and research (HER) system.

The so-called "neoliberalism" ${ }^{1}$ has led the governments of practically all western Europe, the USA, and Latin America to make a set of changes in the labor world with consequences evidently economic, but reaching social life, both in its objective (job market, consumption, and public services), as in its subjective and ethic dimension (environment and sustainability, consumption, innovation, and commodity fetish) (Mészáros, 2001).

Thus, this stage had significant impacts on education, as this area represents a challenging field for neoliberal governments, especially those from countries with a development pattern based on the welfare state, as in France's case.

In the midst of the social question metamorphoses (Castel, 1998), the difficulties in the area of education were felt. In fact, education, as a legally guaranteed social right, imposes high budget investments on the rulers, since it is the space of formation, critical thinking, and the debate of ideas, it is configured as a field of disputes, conflict, and resistance.

Considering universities and research activity from the perspective of these reforms, it is noted that their role has been scaled to a high degree, leaving well-marked contradictions in the path. On the one hand, the university and research are fundamental for overcoming challenges through innovative solutions; on the other hand, there is a pressure to reduce budget, limiting their autonomy and freedom.

At the basis of neoliberal reforms was the crisis of the Fordist production model. In fact, concomitant with neoliberalism, the Fordism crisis gave way to a broad process of restructuring called "flexible accumulation" (Harvey, 1996). Such a model is marked by a direct confrontation with the rigidity of the Fordist mode of production. The new model is based on the flexibility of work processes, job markets, and especially products and consumption patterns. It is characterized by the emergence of entirely new productive sectors, new ways of providing financial services, new markets, and above all, highly intensified rates of commercial, technological, and organizational innovation.

Flexible accumulation involves rapid changes in development patterns across sectors and across geographic regions, creating a vast global movement in areas, such as human health, the environment, information technology, and energy resources. It can be said that it is no coincidence that such areas are now included in the reports of international agencies, such as the United Nations (UN) ${ }^{2}$, which set as the planet's challenges for the millennium: poverty eradication, sustainable agriculture, health and well-being, gender equality, areas of industry, innovation and infrastructure, water/ecosystem life, and coastal resources.

The UN, for instance, urge countries to undertake multidimensional solutions to multi-dimensional challenges. Indirectly, international agencies point to an agenda whose protagonist aims to minimize or overcome the social, environmental, and cultural gaps left by a development model based on inequality. In this context, the knowledge, innovation, and applicability of new solutions become fundamental actors. At the same time, it is vital to say that the call for innovation is also part of contemporary productive strategy, where

\footnotetext{
1 There is a vast literature on the effects of the neoliberal agenda, for a deep approach on the effects of neoliberalismo (see Anderson, 1995, pp. 9-23).

2 The global goals for sustainable development. Global Goals. Retrieved August 10, 2019, from https://www.un.org/sustainabledevelopment/sustainable-development-goals/.
} 
“commodity fetishism”, as defined by Marx in Capital, seems to have reached its highest degree.

It is from this background that this article aims to map the research and innovation system in France, considering that from this mapping it can be identified the aspects of management and governance required.

\section{Methodology}

France has a long and complex history involving HE and science, and therefore has a rich institutional landscape of great diversity of establishments and universities, grandes écoles, institutes that bring in themselves expressions of the long history symbolized by the Sorbonne, since its foundation in 1253 by Robert de Sorbon.

In fact, France has been following the transformations of the current world reflecting the global tendency to stimulate knowledge production with an emphasis on innovation. Obviously, these transformations follow contour lines that shake and redirect the system, especially the impacts resulting from neoliberalism in Europe beginning in the 1990s, as discussed above, but bringing specificities, including those resulting from the agenda of adjustments present in the so-called "New Public Management (NPM) Policy"3, implying a significant contrast to the standards that were characterized in heavy public budgets, mass access, universality, and its derivations.

Not surprisingly, France has undergone an intense process of legal, political, and institutional reorganization, confronting a historical pattern of institutional development with another model of management, financing, production, performance, and evaluation. All of these changes were based on the prerogative that a new position of universities had to be engineered nationally and internationally.

\begin{tabular}{|c|c|}
\hline Law Edgar Faure - 1968 & $\begin{array}{l}\text { - Creates the Établissements à Caractère Scientifique et Culturel (EPCSC). } \\
\text { - The « former colleges » were replaced by Unités d'Enseignement et de Recherche (UER). }\end{array}$ \\
\hline Law Savary - 1984 & $\begin{array}{l}\text { - It included the universities and grandes écoles in the same text called Établissements Publics à } \\
\text { Caractère Scientifique Culturel et Professionnel (EPSCP). }\end{array}$ \\
\hline Process of Bologne - 1999 & $\begin{array}{l}\text { - New training architecture becomes valid throughout Europe, harmonizing higher education in } \\
\text { these countries. }\end{array}$ \\
\hline $\begin{array}{l}\text { Espace Européen de la Recherche (EER)- } \\
\qquad 2000\end{array}$ & $\begin{array}{l}\text { - It establishes European research policy based on scientific excellence, competitiveness, } \\
\text { innovation and cooperation. }\end{array}$ \\
\hline Law April 2006 & $\begin{array}{l}\text { - Creation of two new organizations: the National Research Agency (ANR) and the Agency for the } \\
\text { Evaluation of Research and Higher Education (AERES). } \\
\text { - Establishment of a new legal framework involving the foundations of scientific cooperation. }\end{array}$ \\
\hline Law of 10th August 2007 & • Institute new parameters of Libertés et Responsabilités des Universités - LRU. \\
\hline $\begin{array}{l}\text { Programme d'Investissements d'Avenir } \\
\text { (PIA -1) } 2010\end{array}$ & $\begin{array}{l}\text {-35M Euros a) increase in the financing of projects b) support for the emergence of excellence } \\
\text { centers, combining research organizations and universities c) reinforcing the competitiveness of } \\
\text { the French economy by improving the transfer of public R\&D results to the business world. }\end{array}$ \\
\hline $\begin{array}{l}\text { Programme d'Investissements d'Avenir } \\
\text { (PIA-2) } 2014\end{array}$ & $\begin{array}{l}\text {-12M Euros a) increase in the financing of projects b) support for the emergence of excellence } \\
\text { centers, combining research organizations and universities c) reinforcing the competitiveness of } \\
\text { the French economy by improving the transfer of public R\&D results to the business world. }\end{array}$ \\
\hline $\begin{array}{l}\text { Programme d'Investissements d'Avenir } \\
\text { (PIA-3) } 2017\end{array}$ & $\begin{array}{l}\text {-10M Euros a) increase in the financing of projects b) support for the emergence of excellence } \\
\text { centers, combining research organizations and universities c) reinforcing the competitiveness of } \\
\text { the French economy by improving the transfer of public R\&D results to the business world. }\end{array}$ \\
\hline
\end{tabular}

Figure 1. Documents analyzed.

\footnotetext{
${ }^{3}$ On the NPM policy and its impacts on HE in the European context (see Thoenig \& Paradeise, 2013).
} 
Considering this broad movement of organizational restructuring, it was important for this study, through a methodological point of view, to map out its three structural spheres of the French system of HER, notably: the political sphere, the programming sphere, and the sphere of the system execution. To perform this mapping, it was made a documentary analysis of the legislation and the main regulatory processes of the sector, according to Figure 1.

Given this scenario, it was inevitable to examine the contradictions imposed through the legal and institutional implemented adjustments, since such adjustments generated new routes of funding, evaluation, and organization of academic work and areas of support both in terms of territory and time of the processes organization and their results.

This set of changes inform about the creation of a new socio-institutional pact, involving research organizations, government, and universities, and that this pact was made in an arena of intense disputes about the ethical-political direction of the sector. Thus, the article seeks to characterize what these changes fundamentally mean.

\section{Discussion}

\section{French Innovation System: Re-articulation and Aspects of the Legal Apparatus}

The search for a new legal framework has moved the French HER system. The reforms highlight the efforts of the political sphere to make the system less fragmented and more adapted to international demands.

From the point of view of the French legal apparatus, we can note from the Edgar Faure Law of November 12, 1968, a reorientation of HE institutions, creating the Établissements à Caractère Scientifique et Culturel (EPCSC). The old colleges disappeared and were replaced by Unités d'Enseignement et de Recherche (UER). Units that are based on the principles of autonomy, participation, and multi-disciplinarity. However, it is important to note that this new law, although it has brought a significant change, kept the system divided into two distinct groups: on the one hand, the grandes écoles; on the other hand, the universities.

It was only in 1984, following the same basis of principles-autonomy ${ }^{4}$, participation, and multidisciplinarity - that the Savary Law included the universities and grandes écoles in the same text and promoted more open universities for the outside world, from then on called Établissements Publics à Caractère Scientifique Culturel et Professionnel (EPSCP).

However, this ambiguity_-Universities x the Great Écoles—has become systemic and when added to the fact that research activity has long been linked to external organisms, such as CNRS, it forges a system that is notably known for its fragmentation (Paradeise, 2013).

This feature of the French system has become one of the reforms' targets, with the aim to standardize the system due both to consequences and to the global resource optimization agenda. Thus, the search for overcoming the fragmented character of the system motivated an important part of the ethical-political re-articulation actions undertaken in France.

It is also important to emphasize that, on the one hand, the contraction of the state and the consequent decrease in the demand for hiring personnel, in the neoliberal context, has retracted the role of the Grands Écoles, especially in their social purpose of establishing frames focused on the administrative and economic

\footnotetext{
${ }^{4}$ Administrative autonomy: Universities and Training and Research Units (UTRU) are administered by an elected council and headed by a president and elected officials; pedagogical autonomy: The universities determine the methods of teaching and control of knowledge; and financial autonomy: The financial autonomy of universities was established by the Faure Act of 1968.
} 
system, "The so-called state elites". On the other hand, the consolidation of an international HE assessment and ranking model—carried out by international agencies, such as the Shanghai Ranking, for instance-has led institutions to reorganize themselves into systems that are inseparable between education and research. This conformation led to a reduction in human resources expenditures in the area, as they began to be concurrently allocated to training and research activities (Paradeise, 2013).

Moreover, international pressure has led the Grands Écoles to host a significant research effort, resizing - over the past 20 years - their institutionality beyond their original priority of elite formation. For universities, the impact of globalization has imposed a new aesthetic of "academic excellence", where universities have been forced to change their own conception, redirecting the way traditionally conducted training, "disinterested” research and the promotion of culture, as Paradeise (2013) explained.

Nevertheless, the French system is rich in nuances and has a tradition forged in political principles that derive from the status of equality that underlies French social democracy, whose direction pointed to the massification of access linked to a uniform and centralized legal design from national laws. Thus, one of the visible impacts of globalization was to question this institutional design, weakened by its weight in terms of budget and the international pressure placed by the ranking processes.

Paradeise (2013) stated that French HE is far from the stratified model that prevailed in the United States, where competition and internal differentiation feed an atmosphere of high-performance academic production, fundamentally regulated by parameters that are disseminated by the academic community itself, and funded in the competition circuit, in partnership with external actors. It can be said that the American model has been consolidated in three dimensions: balanced and competent governance, high impact academic lines, internal and external thematic tuning, abundant financial resources, and concentration of professors and students talent (Paradeise, 2013).

Currently, there are 138 EPSCP $^{5}$, including: 19 Communautés D’universités et Établissements, 67 universités, one Institut National Polytechnique, 22 Instituts et Écoles Extérieurs aux Universités, 20 Grands Établissements, five Écoles Françaises à L'étranger, and four Écoles Normales Supérieures. In addition, France also has 95 Établissements Publics à Caractère Administratif (EPA) and other bodies.

The EPSCP aim at the success of all students, the research development, the necessary support for training, the diffusion of knowledge in its diversity, and the increase of the scientific, cultural, and professional level of the nation and its individuals, the economic growth and competitiveness, as well as the implementation of an employment policy that embraces economic, social, environmental, and cultural needs and a foreseeable development; in addition to affirming ethical values, such as fighting against discrimination, reducing social and cultural inequalities, and achieving equality between men and women by ensuring that all those who are willing and capable will have access to the higher forms of culture and research. To this end, they contribute to the improvement of the students' living conditions; promote students' sense of belonging in the community of

\footnotetext{
5 According to current legislation, Article Law 123-3, Loi No, 2013/2013, the public HE service has the following mission: (a) initial and continuing training throughout life; (b) scientific and technological research, dissemination, and exploitation of its results at the service of society. Based on the development of innovation, transfer of technology where possible, the ability to transfer knowledge and support to associations and foundations, recognized as being of public utility, and in the public policies carried out for social challenges and for social, economic, and sustainable development; (c) orientation, social promotion, and professional insertion; (d) dissemination of humanistic culture, in particular through the development of human and social sciences and scientific, technical, and industrial culture; (e) participation in the construction of the European Higher Education and Research Area; and (f) international cooperation.
} 
their establishment, reinforce social cohesion and the development of individual or collective initiatives for the solidarity and motivation of student life; and build an inclusive society. Therefore, it seeks to promote the inclusion of individuals, regardless of their social origin and health condition. Among the French system's goals are the construction of the European research and higher education area and the promotion of territorial attractiveness and influence at local, regional, and national level.

It is worth highlighting the European higher education area aquisition, starting with the Bologna Process (1999). From this point, the French curriculum was reorganized into three grades: Bachelor, Master, and Doctorate (LMD). This new training architecture became applicable throughout Europe and harmonized HE in these countries, facilitating comparison, equivalence, and mobility.

Similarly, the notion of the Espace Européen de la Recherche (EER), created in 2000, reflected the European Union's desire to implement a coherent and concerted European research policy based on scientific excellence, competitiveness, innovation, and cooperation, with the challenge of avoiding the fragmentation of research efforts, fostering cooperation among European scientists.

With regard to the French research system, the Law 2006 of April 2006 can be considered as one of the most significant elements in this process. This law led to the creation of two new organizations to contribute funding (the National Research Agency-ANR) and assessing the French scientific outcomes of research and HE institutions (the Agency for the Evaluation of Research and Higher Education-AERES). This law creates, in the same line, a set of structures designed to facilitate the cooperation among various types of HER institutions, such as the research and higher education networks (PRES) and the thematic networks of advanced research (RTRA). However, what is evident about valuing the innovation at a strategic level was the establishment of a new legal framework involving the foundations of scientific cooperation, conferring the same authority, responsibility, and legitimacy of the research management in order to facilitate and streamline the transfer of knowledge and technologies.

The Center Français des Fonds et Fondations is currently one of the major supporters of foundations in France, expressing a plural field of action both in thematic terms and purpose. In this sense, the new legal framework of foundations meant the consolidation of a field of action in technical and operational terms to develop public policies and innovation ${ }^{6}$.

This same law examines the foundations, reaffirming their importance for the viability of partnerships in

\footnotetext{
${ }^{6}$ Members of the Centre Français des Fonds et Fondations Association des amis de Gustave Eiffel; Association Institut de Myologie AIM; Association Ensemble pour l'éducation Les fondations; Fondation ACOME; Fondation Afnic pour la solidarité numérique; Fondation Alpes Contrôles; Fondation ENA; Fondation d'entreprises ESTIA; Fondation EOVI; Fondation Etoile; Fondation française pour l'archéologie; Fondation François d’Assise; Fondation Jeanine et Maurice Mérigot; Fondation Gustave Roussy; Fondation I3M; Fondation Kronenbourg; Fondation KUNZ; Fondation de la Mer; Fondation Mines TelecomFon; Dation de la mutuelle générale; Fondation Mutac; Fondation Ouishare; Fondation Paris Habitat; Fondation Rémy Cointreau; La Fondation Saint-Irénée; Fondation Samu social de Paris; Fondation Société Générale Solidarité; Fondation SOMFY; Fondation Toulouse Cancer Santé; Fondation Vasgos; Fondation de l’Université de Nantes; Fondation Université Picardie Jules Verne; Fondation Yves Rocher.Besides the associated foundations, the CFF has partnership with the French American Charitable Trust (FACT); Fondation Apprentis d'Auteuil; Fondation de l'Avenir; Fondation Bettencourt Schueller; Fondation Bocuse; Fondation Calouste Gulbenkian; Fondation Caritas France; Fondation Chanel; Fondation Culture et Diversité; Fondation Daniel et Nina Carasso; Fondation de France; Fondation d'entreprise; AG2R La Mondiale; Fondations Edmond de Rothschild; Fondation Entreprendre; Fondation Entreprise Réussite Scolaire ; (FERS) Fondation Fourvière ; Fondation des Gueules Cassées ; Fondation Henriette-Anne Doll; Fondation Hippocrène; Fondation Macif; Fondation Maison des Sciences et de l'Homme (FMSH); Fondation Mérieux; Fondation Notre Dame; Fondation OCIRP; Fondation Pierre Bellon; Fondation Potentiels et Talents; Fondation pour l'Univesité de Lyon; Fondation Robert Abdesselam; Fondation ROVALTAIN; Fondation Saint-Irénée Lyon; Fondation Scaler; Fondation SNCF; Fonds de dotation Après Demain; Fonds de dotation SEPR AVENIR; Institut Pasteur; OMEM (Euvre Montpellieraine des Enfants à la Mer) et Institut Saint-Pierre.
} 
the creation of excellence centers with international visibility. It also establishes confirmed the association between public research organizations and HE institutions through the joint research centers which had developed since the 1990's.

Within the same scope, France approved the Law of 10th August 2007 (Libertés et Responsabilités des Universités_LRU), broadening universities' competences and accountability on budget allocation and human resources management. Its objective was to strengthen the autonomy and broaden the universities' responsibilities, considering sensitive fields, such as the renewal of governance mechanisms, the increase of the Dean's powers, the strengthening of regional and university partnerships, favoring a multiannual planning of the institutions, and finally, the attribution of new responsibilities to institutions, such as personnel payroll management and wealth management.

As it can be noted, much of the efforts undertaken in the context of the re-articulation of the French HE system pointed to the need to overcome the historical fragmentation, however, according to Paradeise's diagnosis (2013), in order for a fragmented system to be effectively recomposed into a concentrated system, it would be required, in addition to the political will of the authorities involved investment, and above all, in the author's words: “an autonomous and radical evolution of the institutions' internal governance”.

\section{From the Public Fund's Global Stagnation to a Segmented Investment Model}

Following the global tendency to pursue rigid behavior with public expenses and the downsizing of the state sector, the policy adopted in France through successive reforms led the French universities to suffer considerable impacts.

Historically responsible for providing open and free access training, the French university is internationally recognized and is one of the most sought after destinations-for training and further education—by students and researchers from around the world ${ }^{7}$. It is worth noting its redistributive role, as it is part of the mechanism of guarantee of rights, forming and opening fields of insertion in the labor market to all social segments.

However, it was in the troubled scenario of the economic crisis that hit European countries, when the unemployment rate among young people in France reached 24.4\% in April 2013, that the lifespan of HE institutions became more evident through against a backdrop of wage conditions, bureaucratic rigidity and difficulties in retaining talent (Paradeise, 2013).

Indeed, it is in this field of funding that the university-Great Écoles Duplicity stands out, for example, in terms of the average expenditure per student: “50,000 euros at the École des Mines x less than 7,000 euros in some universities” (Paradeise, 2013), revealing a fragile imbalance in terms of priority and recognition.

In this sense, the debate arises from the universities ability to produce internal mechanisms in order to overcome the crisis, where the theme of university autonomy (especially financial autonomy) is pointed as a possible exit route. Gradually, the sustainable model becomes a possible answer. In such a model, symbolically played by American universities, competition, and partnership with external actors outweigh public investment.

However, as university autonomy is known, especially in the US, it is followed by what Paradeise (2013)

\footnotetext{
${ }^{7}$ An evidence of this factor is the liveliness of the Cité Internationale Universitaire de Paris-CIUP. Founded in 1925 and located in the heart of Paris, Cité U. receives 12,000 people annually among students and researchers from 140 nationalities; it currently has 40 maisons and a capacity expansion plan and $31 \%$ by 2020. Retrieved August 19, 2019, from http://www.ciup.fr/accueil/les-maisons-et-les-residents-12203.
} 
called the virtuous circle between "autonomy, resources and a balanced governance model", an indispensable circuit for such a model to produce positive results, generating mutual trust between academics and institutions, executive legitimacy for project and partnership management, fundraising, solid reputation, and attraction and retention of talent (professors and students).

In France, although universities have been subjected to a new rationality in terms of budgets, with emphasis on the reduction of direct funding, it is noted that the investment model has remained mostly public, however, its implementation was deepened towards competition, segmentation, and diversification through public notices.

From this point of view, in 2010, the French government launched the Programmed Investissements d'Avenir (PIA). According to the Secrétariat Général pour l'Investissemente (SGPI), the program between 2010 and 2017 has a budget of 57 million euros, distributed as follows:

1. PIA 1: $€ 35$ million (2010)—HE and training: $€ 11$ billion; Research: 8 million euros; Industrial sectors and SMEs: EUR 6.5 billion; Sustainable development: 5 million euros; Numerical economy: and 4.5 million euros.

2. PIA 2: 12 million euros (2014)—HER: € 3.7 million; Energy transition, thermal renovation, and the cities of tomorrow: $€ 2.3$ million; Innovation for a sustainable industry: $€ 1.7$ billion; Technological excellence of the aeronautics and space industries: 1.3 billion euros; Technological excellence of defense industries: 1.5 billion euros; Youth, training, and modernization of the state: 600,000 euros; Digital economy: 600,000 euros; and Health: 400,000 euros.

3. PIA 3: 10 million euros—included in the credits of the Grand Investment Plan (2017)—HER: 2.9 million euros; Research valuation: 3 million euros; and Innovation and business development: 4.1 million euros.

The program is a milestone in the realm of French research and innovation, and is aimed at: (a) increasing the financing of projects, exclusively using procedures of publiccompetition; (b) supporting the emergence of excellence centers, combining research organizations and universities-excellence centers; and (c) reinforcing the competitiveness of the French economy by improving the transfer of public reasech and development (R\&D) results to the business world and the mechanisms for promoting research.

The following graph shows the investments evolution in selected projects and highlights the program size and importance, according to Figure 2 as below:

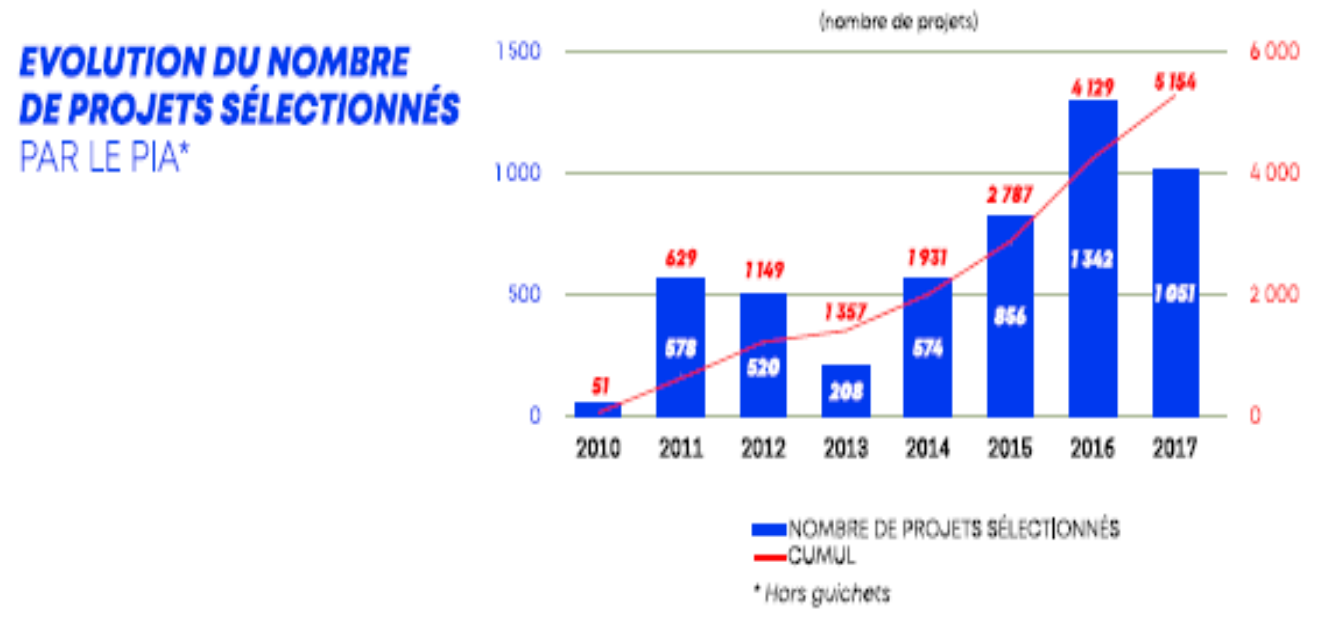

Figure 2. Investments evolution in selected projects-PIA (2010-2017) (Source: SGPI, 2017). 
With such schemes France has established a strategic horizon clarifying the respective roles of political decision-making and actors in charge of implementing funding and assessment of HER institutions.

Although significant, both in terms of the financial volume invested and the relevance of the thematic agenda, the program was not able to create organizational, political, and academic behavior to overcome the obstacles of the old inherited institutional model, especially the issue of autonomy, hindering the international position of French HE. In this regard, HE institutions have organizational, financial, human resource management, and even academic autonomy weaknesses (Paradeise, 2013).

\section{Results}

\section{HE Research and Innovation: General Structure in Articulated Spheres}

The sphere of political-strategic decisions. It can be said that the French HE, research and innovation system is organized from three spheres: the political, the programming, and the executive.

The sphere of political-strategic decisions impacting HE and R\&I in France include the parliament, the government, the ministries, the European research space, and the higher councils of science and technology.

Two higher councils perform in this sphere, the Strategic Research Council, composed of 26 members, responsible for proposing the main guidelines of the national strategy for research, technology transfer, and innovation, and the National Council for Higher Education and Research (CNESER), which is an advisory body of the ministers responsible for HER. CNESER is comprised of 100 members and is chaired by the Prime Minister. It was created in 1968. The composition of this council includes, in addition to representatives of civil society, representatives of students, and regional interests.

Thus, the sphere of political definition (Bobbio, Matteucci, \& Pasquino, 1999) is established at an arena where projects dispute the sector's direction. This affirmation allows us to say that such guidance keeps a bias of tension and provisionality, which explains the constant zigzag in recent years.

Historically, as Paradeise (2012) explained, there is a significant interconnection between the social and economic development model of countries and the design adopted by these countries' universities, making it possible to identify over time three to four major international models.

The Napoleonic model-centralized, with financing under state control and strongly linked to the increasing modernization of countries - this model prevailed in southern European countries. An important feature in this case is their legal status whose prerogative involves nationally all institutions, defining their resources among other parameters, such as nominations, forms of government, and access mechanisms. The Humboldtian model, which brings together Germany and the countries of Northern Europe, is characterized by its independence, seen as a necessary condition for the quality of the produced knowledge. The British model pursues the same goal of independence and is characterized by its independent state financial management. And lastly, and currently a spearhead in terms of what has been considered the "ideal model”, the American model, largely inspired by the Humboldtian, is early distinguished from its European counterparts, placing the emphasis on local organization and financial autonomy, on the notion of "useful knowledge" and the development of close ties with the economy (Paradeise, 2012).

Such models reflect their own institutional cultures, which over time have unfolded into parameters of work organization, academic profile, recognition parameters, decision making, outcome evaluation, etc., dimensions that are grounded and tacitly based within the institutions. 
Heir to the Napoleonic tradition, French HE, although strictly autonomous, has its internal parameters controlled by the political sphere. In order to understand the mutations of the French system today, once again the neoliberal adjustments are identified here in the New Public Management (NPM), according to which mass access and the sector budget suffer towards its retraction, generating a pulsating engine for the funding diversification. A model that follows the neo-recessive wave of many European countries (Paradeise, 2012).

This set of actors has the role of proposing, debating, formulating, legislating, and guiding strategic programs of research and innovation, according to the political, economic, and social interests of the country, as expressed in Figure 3.

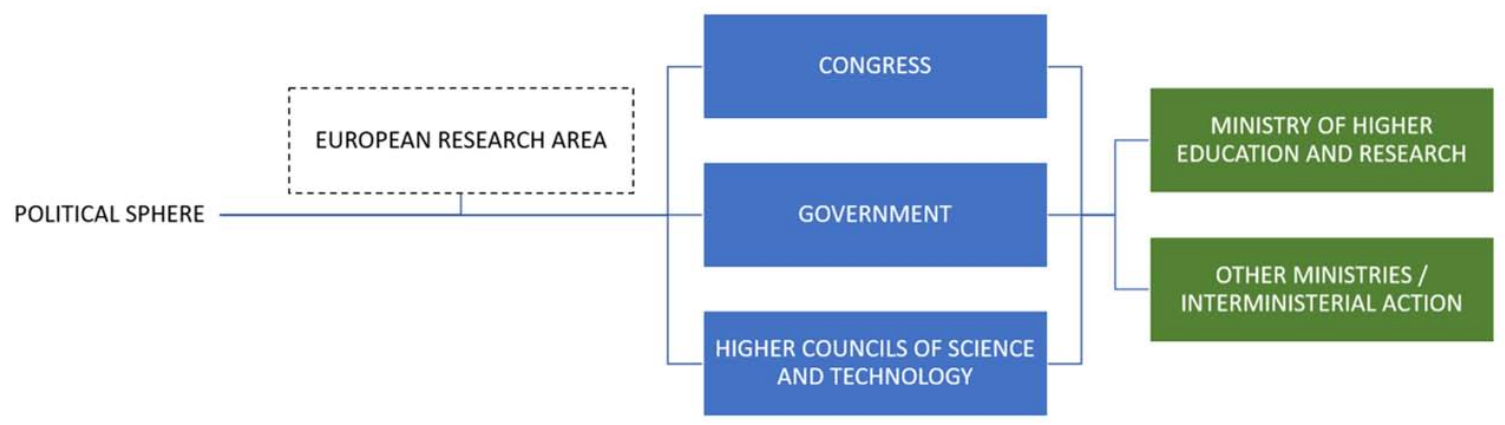

Figure 3. Political and strategic sphere (Source: The author).

The sphere of programming, financing, and evaluation. The remarkable movement of the sphere reflects the most sensitive point of the HE system. In fact, the imposition of a leaner budget model led to the development of new mechanisms of organization, financing, and control in the pursuit, on the one hand, of rationalizing public investment based on the NPM, and on the other hand, the need to provoke academy a new productive behavior vis-à-vis international competition and the role of knowledge in economic dynamics in a "knowledge society" (Paradeise, 2012).

From such references, it is possible to identify another area of the system, the sphere that involves programming agencies, whose purpose is to recognize and make projects feasible according to their excellence standards.

Therefore, National Research Agency (ANR), BpiFrance Financement (ex OSEO), AERES, and the foundations are part of the programming area.

Founded in 2005, the ANR has been responsible for developing and publishing the Annual Action Plan for Research and Innovation, meant to implement the so-called "National Research Strategy" (Stratégie Nationale de la Recherche-SNR) that identifies parameters defined by the system’s sphere (Décret 2014-402 du 16 avril 2014).

The national strategy for research and technological development, according to the ANR, aims to: (a) increase knowledge; (b) share the scientific, technical, and industrial culture; (c) promote research results at the service of society. To that end, it focuses on the development of innovation, the transfer of technology where it is possible, on the expertise capacity and support to associations and foundations, recognized as public utility and on policies to social challenges, social development needs, economic and sustainable development; and (d) promote the French language as a scientific language.

The ANR's actions must encompass the so-called "social deficits", such as:

(a) resource and climate change management; 
(b) clean, safe, and effective energy;

(c) healthy living and well-being;

(d) food security and population deficit;

(e) mobility and durable urban systems;

(f) information and communication society;

(g) innovative, integrative, and adaptive society;

(i) freedom and security of Europe, its citizens and residents.

From the financing point of view, the ANR establishes two categories of funding: thematic programs, which account for $50 \%$ of the budget; exploratory research programs (White Program, Jeunes Chercheurs Program, Post-Doc Return Program, Chairs of Excellence Program, and International White Program), targeted by the other $50 \%$ of the available resources.

Currently, according to the Ministry of National Education, HER, 431,100 people work in this sector, including 284,800 researchers. Data from 2016 report that France invested 2.2\% of its gross domestic product (GDP) in research, as shown in Figure 4, development and innovation:

\begin{tabular}{lr}
\hline Recherche - Développement - Innovation* & (2016) \\
\hline Dépense intérieure de R\&D (DIRD*) en 2016 (en Md€) & 49,5 \\
Dépense intérieure de R\&D des entreprises (DIRDE*) (en Md€) & 32,2 \\
Dépense intérieure de R\&D des administrations (DIRDA*) (en Md€) & 17,4 \\
DIRD / PIB (en \% du PIB) & 2,2 \\
& \\
Effectifs de la R\&D en 2016 (en ETP*) & 431100 \\
Chercheurs* en 2016 (en ETP) & 284800 \\
Personnels de soutien* en 2016 (en ETP) & 146300 \\
& \\
Sociétés innovantes en 2016 (en \%) & 51
\end{tabular}

Figure 4. Investment in research and innovation (Source: Ministère de l’Enseignement supérieur, de la Recherche et de l'Innovation [MESRI]).

Therefore, it is worth noting that the sphere of programming comprises research organizations, which are subdivided as follows: the Etablissements Publics Scientifiques et Technologiques_EPST involve the Center National de Recherche Scientifique (CNRS), the Institut National de Recherche (INRIA), the Institut National de la Recherche Agronomique (INRA) and the Institut National de la Santé et de la Recherche Médicale (INSERM); and the Etablissements Publics à Caractère Industriel et Commercial-EPIC, which involve the Commissariat à l'Energie Atomique et Aux Énergies Alternatives-CEA, and the Center National d'Etudes Spatiales-CNES. Foundations, such as the Pasteur Institute, the Curie Institute, etc. And the BpiFrance Financement (formerly OSEO) that fund innovation companies-especially Start Ups as well as Micro- and Small Enterprises - at all stages of their development - in credit, guarantee, and equity. Bpifrance offers follow-up of innovation projects and internationalization of these companies.

Support includes counseling, partnership with the university, networking, and acceleration program ${ }^{8}$.

The system also receives funding from the competitive schemes of other organizations, such as the European Community Resources. As shown below, France received $€$ 3,761,102.493 billion for investment in research and innovation, according to data from 2019 (see Figure 5).

\footnotetext{
${ }^{8}$ Retrieved from http://www.bpifrance.fr.
} 


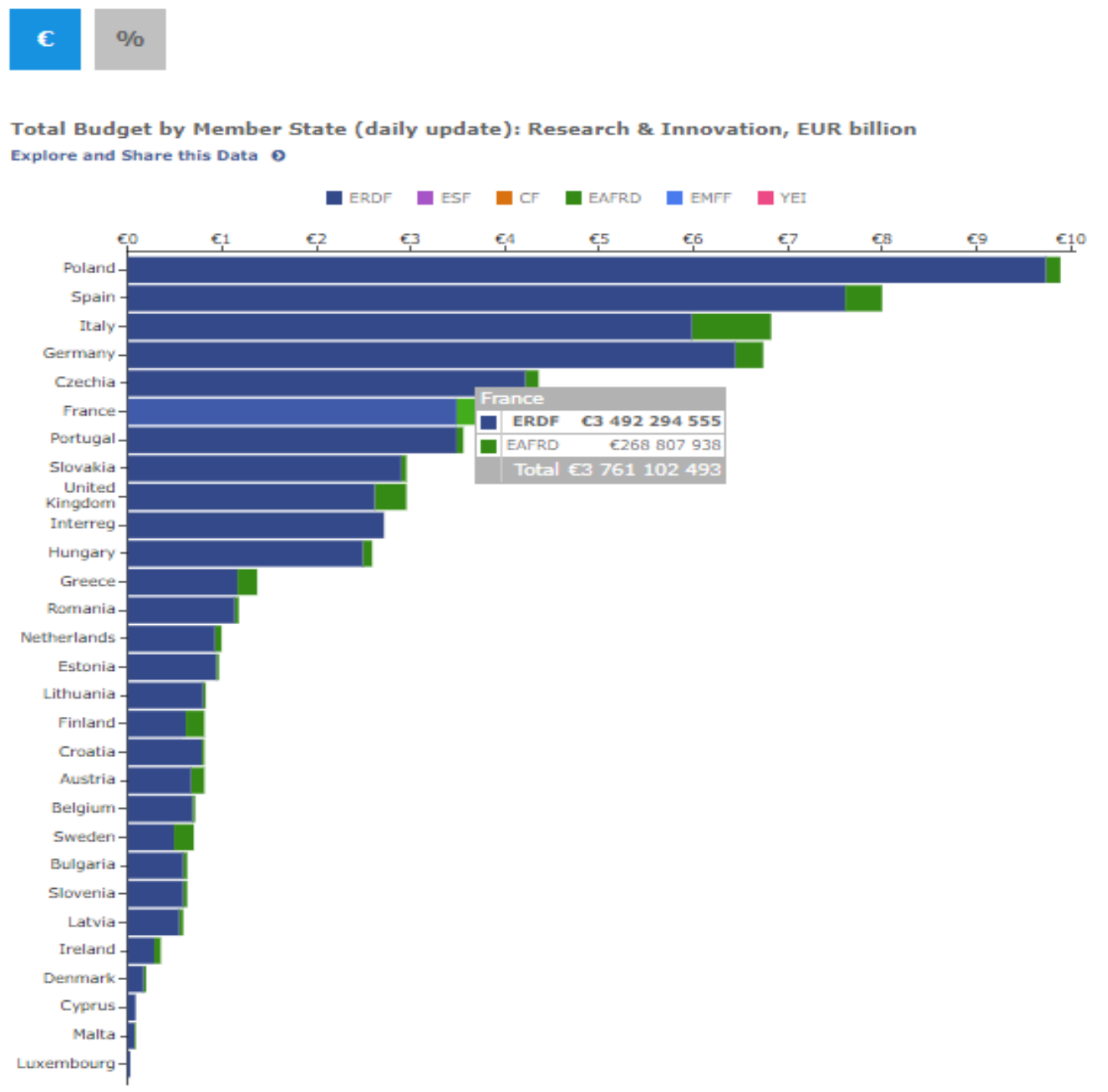

Figure 5. Budget by member state: European Community Resources (Source: Retrieved from https://cohesiondata.ec.europa.eu/themes/1).

In addition, it is identified in the sphere of programming, financing, and evaluation:

The Ministères de l'Europe et des Affaires Étrangères (MEAE), de la Défense, des Transports, as regions and companies based on shared interests and stimulated by the development of the Pôles of Compétitivité.

In the field of evaluation, Law 660 of July 22, 2013 created the Higher Council for the Evaluation of Research and Higher Education (HCÉRES), which replaced the AERES on November 17, 2014. Its organization and its missions are defined by Decree No. 2014-1365 of November 14, 2014 ${ }^{9}$. The following Figure 6 represents the actors' procedure in the scope of programming, financing, and evaluation.

\footnotetext{
${ }^{9}$ In order to guarantee its mission the evaluation body enjoys the status of independent administrative authority, which allows it the impartiality of its evaluations against the evaluated parties or other interested parties' influence. Its reports are publicly accessible, respecting the principle of transparency of all its methods and procedures, conducting its actions in accordance with international standards and European guidelines for quality guarantee in HE. Its mission is to evaluate all HER institutions in France (universities, grandes écoles, research organizations, HE institutions, research units, doctoral schools, courses $\mathrm{L} / \mathrm{M} / \mathrm{DLicence} /$ Master/Ph.D.); validate the assessment procedures implemented by other agencies; evaluate, according to demand, foreign HE institutions; produce analyzes and indicators based on the work of the observatories of science and technology (OST), department of Hcéres; contribute to the definition of a national policy of scientific integrity (NPSI), observing practices and support actors in the implementation of its duties, counting on the French office of scientific integrity (OFIS), Department of Hécéres. Retrieved from https://www.hceres.fr/sites/default/files/media/downloads/Hceres_Plaquette_Presentation.pdf.
} 


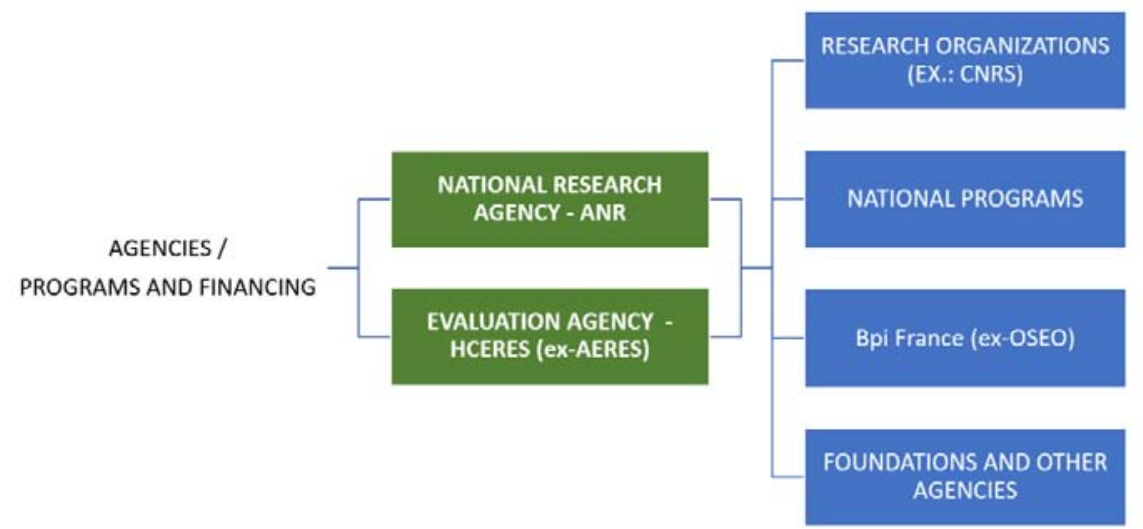

Figure 6. Sphere of programming and financing of the research and innovation system (Source: The author).

The operational sphere. Finally, at the base of the system is the operational sphere, Figure 7, which is composed of a rich architecture, from research units, universities, Grandes Écoles, HE establishments, actors involved in the commercialization and evaluation committees (HCERES).
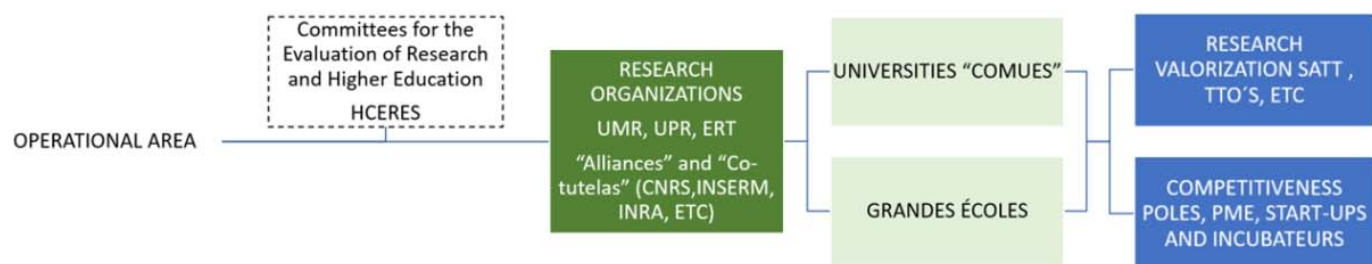

Figure 7. Sphere of production of the research and innovation system (Source: The author).

The research units can be joint research units (UMRs), clean research units (UPRs), or technological research teams (TRTs). Such units are multi-management connected to one or more research organizations, for example, CNRS, INRA, etc ${ }^{10}$. The UMR creation, evolution, or elimination is a prerogative of the Ministry of HER, which is based on the HCERES five-year evaluation.

The TRTS are teams that, in partnership with the industry, conduct medium term researches in the scope of projects that seek to remove technological blocks related to problems that do not have immediate solutions.

Following a strategy of strengthening the network of collaborations among universities, research centers, and other organizations, in order to combine academic and expertise interests by sharing skills, resources, and scientific production culture, the Centers of Research and Higher Education (PRES) were created. Soon after

\footnotetext{
10 The UMR allow for the collaboration of various institutions of HER in the same laboratories, such as: CNRS-Centre National de la Recherche Scientifique; INRA; INSERM —-Institut National de la Santé et de la Recherche Médical; CEA—Commissariat à l'Energie Atomique et aux Energies Alternatives; INSEE-Institut National de la Statistique et des Etudes Economiques; Instituts Curie et Pasteur; ADEME-Agence de l'Environnement et de la Maîtrise de l'Energie; ANDRA—Agence Nationale pour la gestion des Déchets Radioactifs; BRGM-Bureau de Recherches Géologiques et Minières; IFP-EN-Institut Français du Pétrole-Energies Nouvelles; IRSTEA-Institut national de Recherche en Sciences et Technologies pour l'Environnement et l'Agriculture; CIRAD—Centre de coopération Internationale en Recherche Agronomique pour le Développement; CEE—Centre d'Etudes de l'Emploi; ONED_Observatoire National de l'Enfance en Danger; CNES-Centre National d'Etudes Spatiales; IFREMER - Institut Français de Recherche pour l'Exploitation de la MER; INED_-Institut National des Etudes Démographiques; INRA - Institut National de la Recherche Agronomique; IFSTTAR_-Institut Français des Sciences et Technologies des Transports, de l'Aménagement et des Réseaux; INRIA — Institut National de la Recherche en Informatique et en Automatique; INRS—Institut de Recherche et de Sécurité; and IRD—Institut de Recherche pour le Développement.
} 
the law of July 22, 2013 created the communautés d'universités et d'établissements (COMUES). It is the EPSCPs that coordinate training offers and strategies for research and transfer of HE institutions. The COMUES $^{11}$ replaced the PRES. This strategy is expressed through the so-called "alliances". The "alliances" were created between 2009 and 2010 to foster inter-organizational coordinations in five fields:

(a) Alliance Nationale pour les Sciences de la Vie et de la Santé (Aviesan);

(b) Alliance Nationale de Coordination de la Recherche pour l'éÉnergie (Ancre);

(c) Alliance des Sciences et Technologies du Numérique (Allistene);

(d) Alliance Nationale de Recherche pour l'Environnement (AllEnvi);

(e) Alliance Thématique Nationale des Sciences Humaines et Sociales (Athéna).

This strategy has become a significant factor of transformation in the life of universities, since such alliances have generated new opportunities, especially in relation to a new position of the establishments in the territory, constituting new identities in terms of their mission in face of society's demands. "French universities have thus begun to contour, to differ in fact, if not in law, to show reputations around their strengths ..... Thus, recent laws on university research and autonomy should be understood as the conclusion points of a reform process in the French academic system, not as its inaugural point” (Paradeise, 2012; Musselin \& Paradeise, 2008).

Operational HER institutions include, under one or the other of these legal forms, universities, and schools, such as public engineer schools-Polytechnique, etc.; private or semi-private engineer schools-Centrale; Instituts d'Etudes Politiques; Ecole Nationale d'Administration; Business Schools; etc. Companies may be formally involved, for instance, through centers of competitiveness and programs of entrepreneurship and innovation.

The research center is the basic cell of the research system. A research center or laboratory usually associates HE institutions and public research organisations that support it with human resources (researchers, professors enseignants-chercheurs [EC], professeur or Maître de Conférences, engineers, technicians, administrative staff, doctorates, post-doctorates, etc.) and basic funding.

A laboratory can belong to a GdR, a FR, or a IFR, as follows:

(a) GdR: Groupement de recherche, a structure from the CNRS that brings together a scientific community workingin the same thematic area;

(b) FR: Fédération de recherche, grouping several laboratories or teams for the construction of interdisciplinary projects, complementary works, and platform sharing;

(c) IFR: Instituts Fédératifs de recherche, federal research units that explore a common scientific strategy of excellence based on the complementarity of the actors as well as other structuring modalities.

Obviously, the way a laboratory works depends on its size, which may vary from a dozen of people to several hundreds. However, it is possible to say that there is a minimum structure that forms the basis of most of the research laboratories in France, which comprise a director, who is responsible for the laboratory, an administrative officer, research teams, responsible for the coordination of research groups, the laboratory council, where the main decisions of the laboratory scientific orientations and daily life are debated, and occasionally an external scientific council.

\footnotetext{
11 Article Law 718-2 - In a given territory, which may be academic or inter-academic, based on a shared project, public institutions of HE under the Ministry of HER partners coordinate their training offer and strategy research and transfer of knowledge.
} 
Besides, it is important to mention the National AERES, Law of July 22, 2013, decree of November 2014. The AERES (which muted in 2012 to HCERES) assesses laboratories, teaching departments, and institutions as wholes. It recruits ad hoc evaluation committees that generate reports. Its purpose is to introduce transparency on these entities performance. As far as research centers are concerned, its evaluation is based the following criteria:

(a) production and scientific quality;

(b) influence and academic attractiveness;

(c) interaction with the social, economic and cultural environment (interaction with society);

(d) organization and unit life (teams);

(e) impact on training;

(f) strategy and planning for the next five years.

Such indicators allow institutions to identify, measure, and place each of their dimensions in terms of performance. On the horizon are two points, the valorization of the "brand" and the international position vis-à-vis the classification in the ranking processes (Paradeise, 2012).

Both the evaluation agency-HCERES and the research agency-ANR, contribute progressively to consolidate the funding model based on segmentation and competition among researchers.

Thus, it is possible to visualize an articulated gear between the model of evaluation, financing, and performance, be it in terms of training, research, or innovation.

\section{PANORAMA OF RESEARCH AND INNOVATION IN FRANCE: POLITICS, PROGRAMS AND ACTORS}

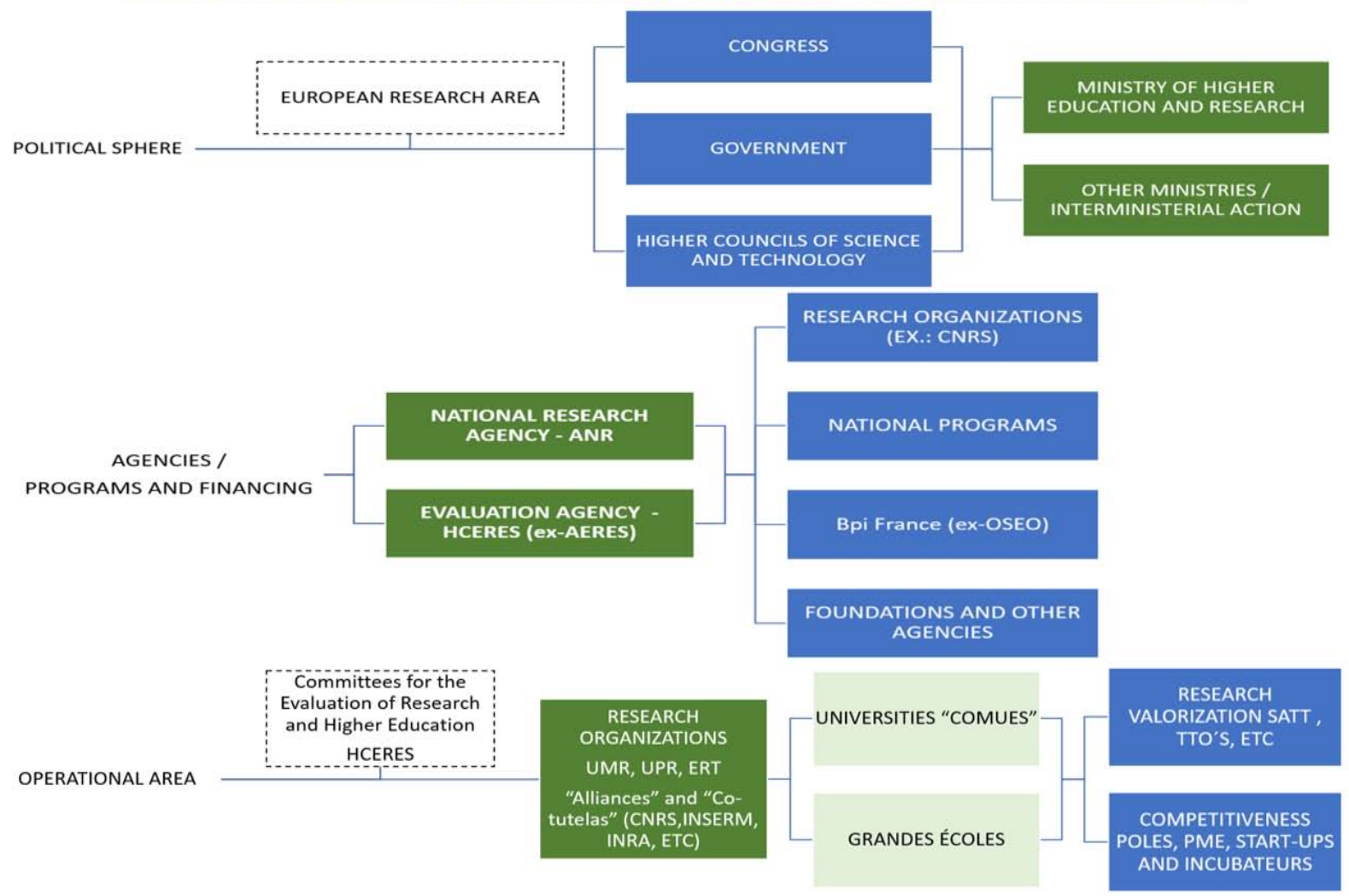

Figure 8. Panorama: Politics, programs, and actors in France (Souce: The author). 
According to Paradeise (2012), the changes in the French HE system are thus part of a globalized movement of reorganization of the sector. "The trajectories are different, but the deep ongoing French mutation seems to be derived from a reference model already practiced in several countries” (Paradeise, 2012, p. 9).

Basically, the system described in such reports can be summarized by using the above chart (see Figure 8).

Indeed, this system should not be seen as some harmonious sum of the functions and purposes of each entity in each sphere of the production system.

\section{Conclusions}

The mapping of the system helps raising some issues about the articulation of the system, such as the socio-political context that impacted its legal and strategic reordering over the last 20 years and its rationale in the context of a "knowledge society" (Paradeise, 2009).

It can be affirmed that the transformations that were felt in France are part of a broader process within the scope of the globalization of HE. Its main characteristics are: The rationalization of the resources coming from public funds, the restriction of the universal character of such resources implementation in favor of fragmentation, especially by competition in bids, the thematically research direction, either in the proportion by area, the valorization of innovation and projects with potential for technology transfer, the expansion of the university's role for the social and economic development of the territory, the political appropriation of the university's role for the sustainability of the planet, the funding associated with results (bibliometrics), the sophistication of evaluation systems and their indicators, encouragement of the system of local, national, and international alliances with the creation of mixed research units, and the implementation of correlated management and governance models.

As a consequence, reform seems to undermine the principle of equality and freedom, the "unfulfilled" principles of modernity, since in its place it proclaims competition and control, leading HE, research, and innovation to an agenda that could be considered "postmodern" 12 .

The study showed that current legislative developments have had strong effects and brought to light a narrative that points to the polarization between the fight against a supposedly ineffective model, regulated by the academy, bureaucratic and organized in "fiefdom" versus a competitive, segmented, and organized model from a quasi-market logic.

In this narrative the notion of innovation has become a kind of panacea, where everything associated with the logic of innovation has in itself a positive social dimension in the eyes of the instituted indicators.

In addition, the university's own role as an agent for promoting equity is being lost on the horizon, as opposed to the need to improve institutional position in the international ranking frameworks.

The university's mission is multi-dimensional (Paradeise, 2012), in this sense, considering the HE's function, the hierarchy of importance among research, innovation, training, support for social mobility, support for local development, and culture promotion is senseless. Between the model of competition and the return to a model of "feudal" powers should prevail the university ethically committed to human rights, the preservation of the environment, besides the necessary freedom and inherent in the knowledge production.

\footnotetext{
12 One of the most evident features of postmodernity is the mechanisms that lead to the fake of reality. In the case of HE, for example, the strong effects of international ranking systems generate quite questionable conclusions, establishing from criteria that when placed out of context impose through their results the symbolic disqualification of institutions. About the modernity and post-modernity debate (Jameson, 2002).
} 
Thus, each institution should seek its position, looking to the future in order to articulate itself autonomously to the present challenges of democratic societies.

It is necessary to broaden the dialogue between the actors involved with public policies, evaluation criteria and institutions, giving a privileged place to the daily challenges, ambitions, and strategies of each establishment to better direct the ways of financing, and understanding $\mathrm{HE}$ as a field in permanent transformation since the specificity and the raw material of its work is man, nature, and its inexhaustible relationship.

\section{References}

Anderson, P. (1995). Balance of neoliberalism. In E. Sader and P. Gentili (Eds.), Post-neoliberalism: Social policies and the democratic state (pp. 9-23). Rio de Janeiro: Peace and Earth.

Bobbio, N., Matteucci, N., \& Pasquino, G.(1999). Policy dictionary (Vol. 2, 12th ed.). Brasilia: Publisher UnB.

Castel, R. (1998). The metamorphoses of the social question: A wage chronicle. (D. P. Iraci, Trans.). Petrópolis, RJ: Vozes Publisher.

Ferlie, E. (2009). The governance of higher education systems: A public management perspective. In University governance: Western European comparative perspectives. France, BV: Springer Science + Business Media.

Harvey, D. (1996). Postmodern condition: A research into the origins of cultural change (6th ed.). São Paulo: Loyola.

Jameson, F. (2002). Postmodernism - The cultural logic of late capitalism. São Paulo: Ática.

James, A. E. (2010). Industry collaboration, scientific sharing, and the dissemination of knowledge. University of Chicago, USA.

Laredo, P. (2007). Revisiting the third mission of universities: Toward are new edcategorization of university activities. Higher Education Policy, 20, 441-456.

Marx, K. (1985). Capital: Criticism of political economy (Vol. 9, No. 1., Col. The Economists). São Paulo: Abril Cultural.

Mészáros, I. (2001). Beyond capital: Towards a transition theory/IstvánMészarós. Paulo Cezar Castanheira, Sérgio Lessa (1st ed. Magazine). Sao Paulo: Good time.

Paradeise, C. (2009). University governance: Western European comparative perspectives. (E. Ferlie, I. Bleiklie, \& E. Reale, Eds.). Springer, Dordrecht.

Paradeise, C. (2012, December). Global challenges and university traditions: European comparisons. France, Esprit.

Paradeise, C. (2013, November 25). France facing the current dilemmas of higher education in the world. Communication at the Academy of Moral and Political Sciences.

Paradeise. C., \& Filliatreau, G. (2016). The emergent action field of metrics: From rankings to altmetrics. The University Under Pressure Researchin the Sociology of Organizations, 46, 87-128.

Thoenig, J. C., \& Paradeise, C. (2013). Academic institutions in search of quality: Local orders and global standards. Organization Studies, 34(2). 